University of Nebraska - Lincoln

DigitalCommons@University of Nebraska - Lincoln

2012

Drop weight testing on sandwich panels with a novel thermoplastic core material

Christopher Y. Tuan

University of Nebraska-Lincoln, ctuan1@unl.edu

Follow this and additional works at: https://digitalcommons.unl.edu/civilengfacpub

Part of the Civil Engineering Commons

Tuan, Christopher Y., "Drop weight testing on sandwich panels with a novel thermoplastic core material" (2012). Civil Engineering Faculty Publications. 44.

https://digitalcommons.unl.edu/civilengfacpub/44

This Article is brought to you for free and open access by the Civil Engineering at DigitalCommons@University of Nebraska - Lincoln. It has been accepted for inclusion in Civil Engineering Faculty Publications by an authorized administrator of DigitalCommons@University of Nebraska - Lincoln. 
Published in Journal of Sandwich Structures and Materials I4:3 (2012), pp. 325-338;

doi: I0.1 I77// 0996362/2444748

Copyright () 2012 Christopher Y. Tuan; published by Sage Publications.

Used by permission. http://jsm.sagepub.com

\title{
Drop weight testing on sandwich panels with a novel thermoplastic core material
}

\author{
Christopher Y. Tuan \\ Civil Engineering, University of Nebraska-Lincoln, Omaha, NE, USA \\ Correspondence: Civil Engineering, University of Nebraska-Lincoln, Peter Kiewit Institute, \\ I I 10 South 67th Street, Omaha, NE 68I82, USA; email ctuan@unomaha.edu
}

\begin{abstract}
A series of drop weight tests were conducted to evaluate the dynamic flatwise compression strength and flexural strength of sandwich panels with a novel core structure. This sandwich core material, known as Norcore, consists of interconnected cells in a unique configuration of truncated pyramid with sloping cell walls. Core materials made of thermoplastic including virgin Lexan, polycarbonate, polycarbonate regrind, high-impact polystyrene, and acrylonitrile butadiene styrene were tested. The test results showed that these sandwich panels have good strength as well as energy absorption capacities.
\end{abstract}

Keywords: sandwich panels, impact loading, drop weight tests, energy absorption, thermoplastics

\section{Introduction}

Conventionally, sandwich panels are made up of two stiff and strong facings separated by a lightweight core. While aluminum and fiber-reinforced plastics are commonly used for the facings of sandwich construction, the core is generally made from monolithic materials in a repeated cell pattern. The development of lightweight, high-strength core materials has led to potential applications for blast resistance. For instance, these sandwich panels can be airlifted to forward bases where shelters or protective structures can be constructed expediently with 
indigenous materials and labor. In this case, the strength/stiffness-to-weight ratio and impact energy absorption capacity are essential design parameters. Gibson and Ashby [1] provide detailed design guidelines for sandwich panels based on the failure modes including face yielding, face wrinkling, core failure, and delamination of facing from the core.

In this paper, the dynamic strength of a novel sandwich panel structure due to the impact of a drop weight was studied in detail. The results are compared to the static test results published in the literature. The tests conducted are the ASTM C365 - flatwise compressive strength and the ASTM D790 - three-point loading flexural strength tests. The impact energy absorption capacities of several thermoplastic core materials are presented.

\section{Novel core cell structure}

A core material, known as Norcore [2], is manufactured by stretching a thin solid sheet of thermoplastic placed between two heated die plates. This core material has features of both a dense elastic solid and those of a foam-type material. This novel cellular structure is similar to a traditional honeycomb core and that of an egg crate. Due to the forming process used in creating this sandwich core material, it is possible to control the cell wall thickness and relative density associated with cellular structure configurations. Figure 1(a) and (b) shows the top view and the edge view of a typical Norcore panel, respectively. Tuan and Sierakowski [3] studied the unique cell geometry of Norcore and compared finite element simulation results with test data.

The fabrication process of these core panels is shown in Figure 2. The vents are used to create a vacuum between the plates. The cell structure of the core resulting from this process is a series of interconnected truncated cones. These cores have variable cell thickness, strength, and stiffness, the selection of which is dependent upon a particular application. The stretched core thus formed has a stiffness of 50 to 100 times that of the original extruded sheet, and with the addition of facings, the resultant sandwich construction may have a stiffness of 300 to 1000 times that of the original extruded sheet. Some of the physical and mechanical properties of these sandwich panels with aluminum facings from the manufacturer are given in Table 1.

\section{Drop weight tests}

\section{Drop weight testing facility}

A drop weight testing facility is set up in the Structural Research Laboratory at the Peter Kiewit Institute, Omaha, Nebraska. The setup was designed to deliver impulsive loading onto a test specimen. As shown in Figure 3, the facility is composed of a strong foundation, steel supports, a strong wall, a PVC pipe drop chute, and a drop weight. 
(a)

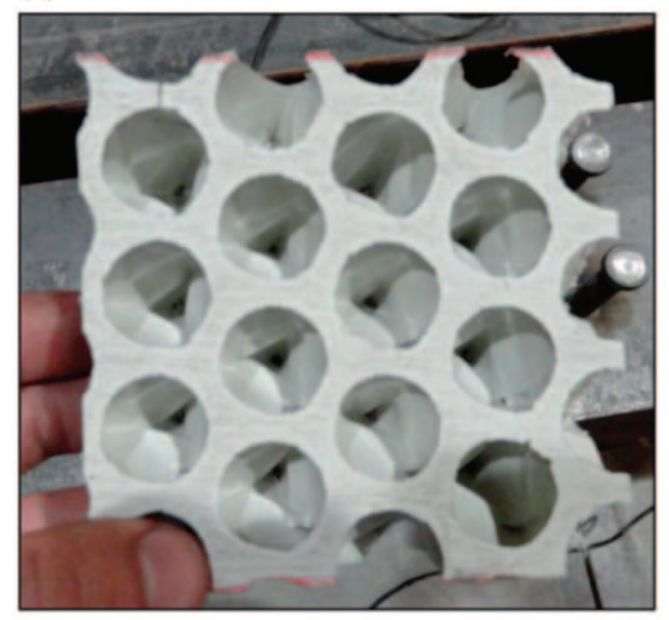

(b)

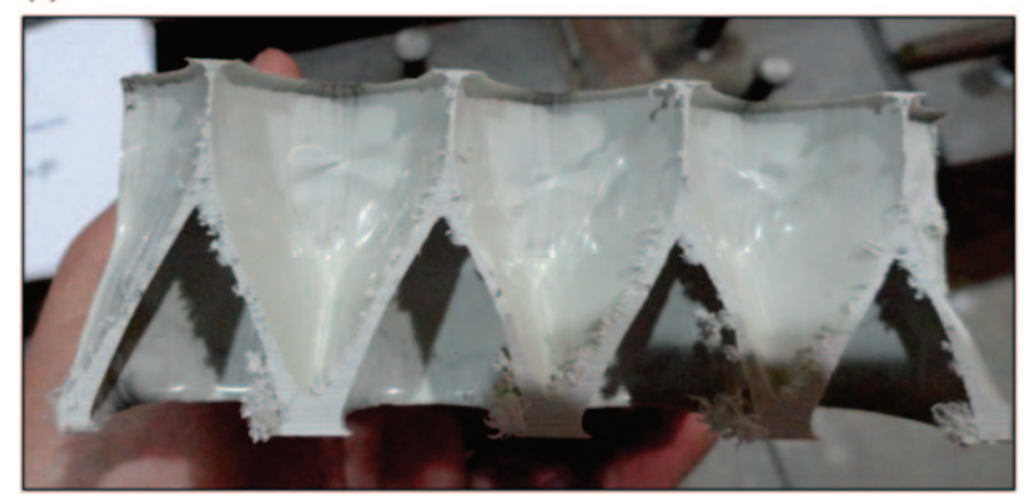

Figure I. Cell structure of Norcore. (a) Top View (b) Edge View.

The steel supports are firmly fixed to the foundation. The drop weight is made of a 5.625-in. (143mm) diameter steel cylinder and a 1.5-in. (38 mm) steel rod welded to the end for impact tup. The cylinder had four skids welded at equidistance along the surface as stabilizers in the PVC drop chute. One-inch (25 mm) holes are drilled along the PVC pipe at 2-, 3-, 4-, and 5-ft (0.6, 0.9, 1.2, and $1.5 \mathrm{~m})$ drop heights. The total weight of the drop weight is 72.3 pounds $(321.6 \mathrm{~N})$. The drop weight is lowered into the drop chute at a drop height by means of a rope going over a pulley. The drop weight can be quickly released by detaching the rope from the anchor on the concrete floor. The drop weight tests conducted were the flatwise compressive strength and three-point simple beam flexural strength tests. The specimens used for the flatwise compressive strength drop weight tests 

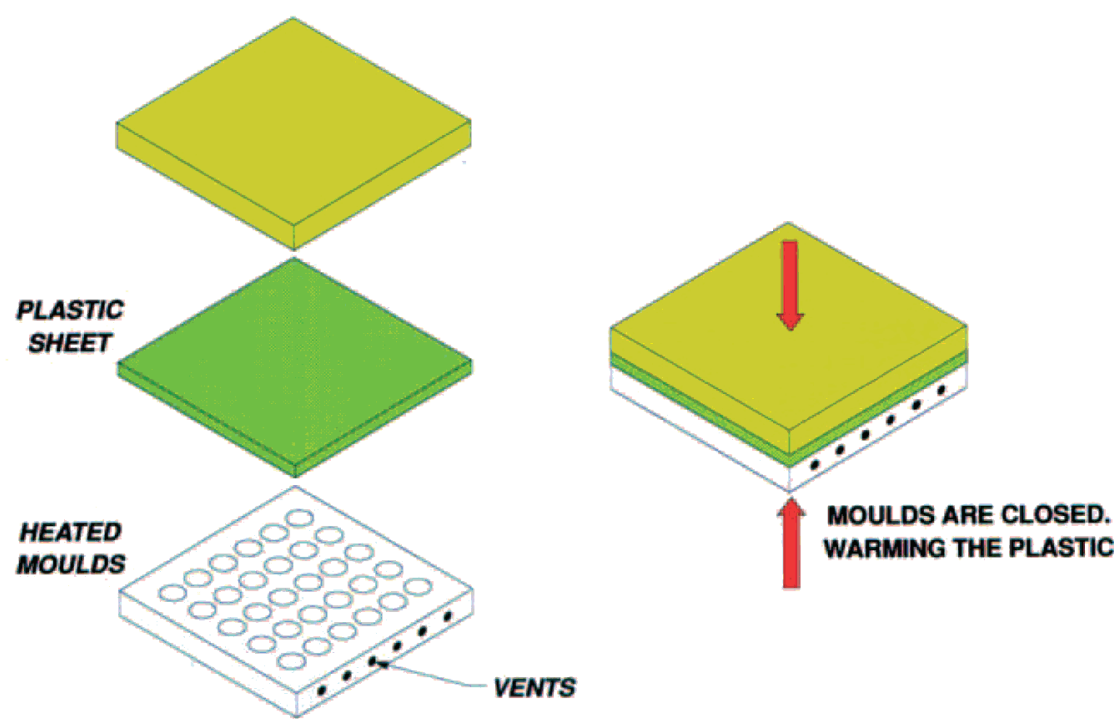

Figure 2. Fabrication process of Norcore.

Table I. Mechanical properties of I-in. Norcore core with 0.023 -in. aluminum facings

\begin{tabular}{|c|c|c|c|c|c|}
\hline Property & ASTM test & Units & HIPS & PC & $A B S$ \\
\hline Flexural strength ${ }^{\mathrm{a}}$ & D790 & Psi & 343 & 587 & - \\
\hline Flexural strength & D790 & Psi & 1146 & 1538 & 1897 \\
\hline Flexural modulus & D790 & Psi & 317,000 & 210,000 & 431,000 \\
\hline Shear strength & C393 & Psi & 105 & 142 & 170 \\
\hline Shear modulus & C393 & Psi & 5000 & 3100 & 7000 \\
\hline \multicolumn{6}{|c|}{ Flatwise compressive } \\
\hline Ultimate load & C365 & $\mathrm{Lb}$ & 3990 & 2620 & - \\
\hline Strength & C365 & Psi & 250 & 164 & - \\
\hline \multicolumn{6}{|c|}{ Edgewise compressive } \\
\hline Strength ${ }^{\mathrm{a}}$ & C364 & Psi & 167 & 199 & - \\
\hline Strength & C364 & Psi & 16,200 & 14,270 & - \\
\hline
\end{tabular}

ABS: acrylonitrile butadiene styrene; HIPS: high-impact polystyrene; PC: polycarbonate;

I in. $=25.4 \mathrm{~mm}$; I psi $=6.9 \mathrm{kPa}$; and I lb $=4.45 \mathrm{~N}$.

a. Test data without facings.

were 1-in. ( $25 \mathrm{~mm})$ or 1.5-in. (38 mm) thick, 4 in. by 4 in. $(102 \mathrm{~mm} \times 102 \mathrm{~mm})$ square panels without facings, and those for the bending tests are $12 \mathrm{in.} \mathrm{(305} \mathrm{mm)} \mathrm{long}$ and 4 in. $(102 \mathrm{~mm})$ wide core with 0.032 -in. $(0.81 \mathrm{~mm})$ aluminum facings. These test specimens were supplied by the manufacturer. 

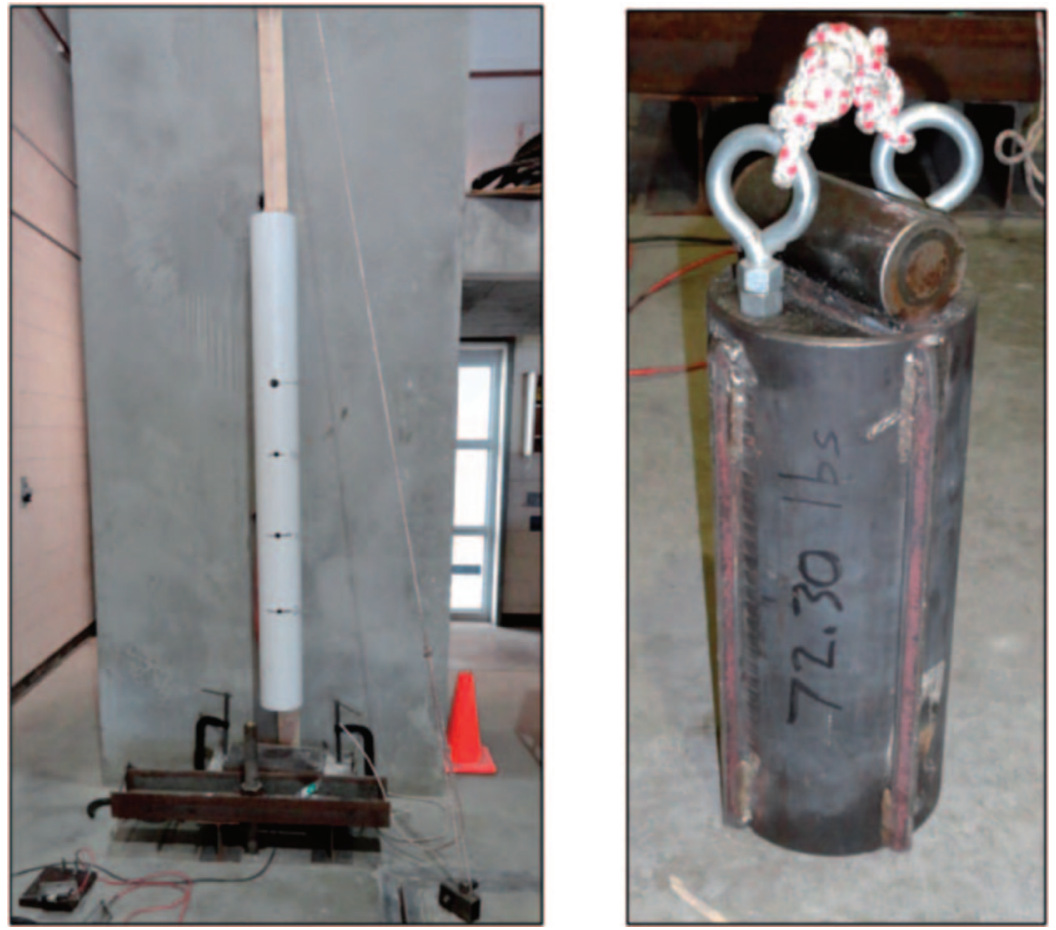

Figure 3. Drop weight testing setup.

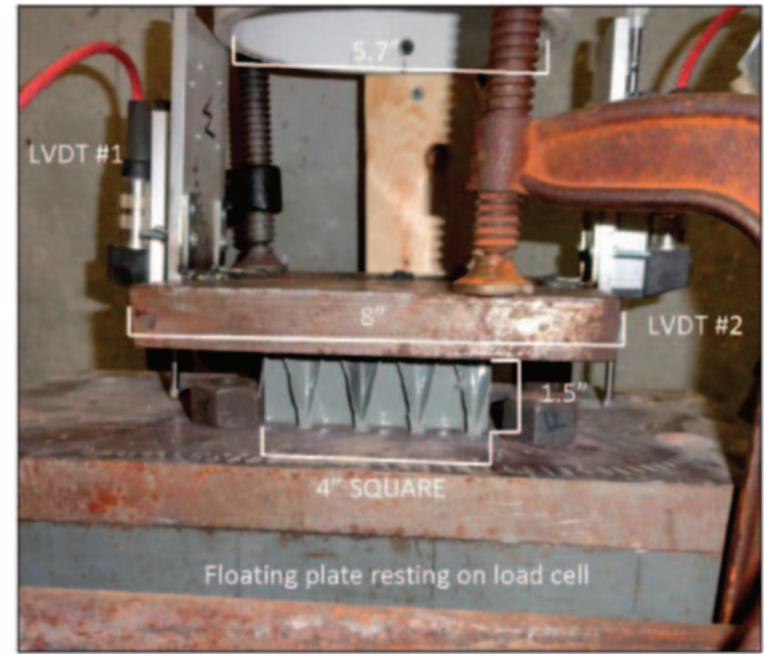

Figure 4. Flatwise compression test setup. 
(a) Flatwise Compression Tests

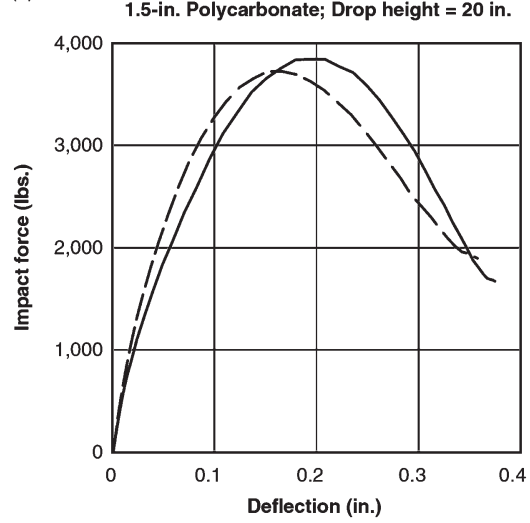

(b)

Flatwise Compression Tests

1-in. PC-regrind; Drop height $=22$ in

(c)

Flatwise Compression Tests 1.5 -in. ABS, Drop height $=20$ in.
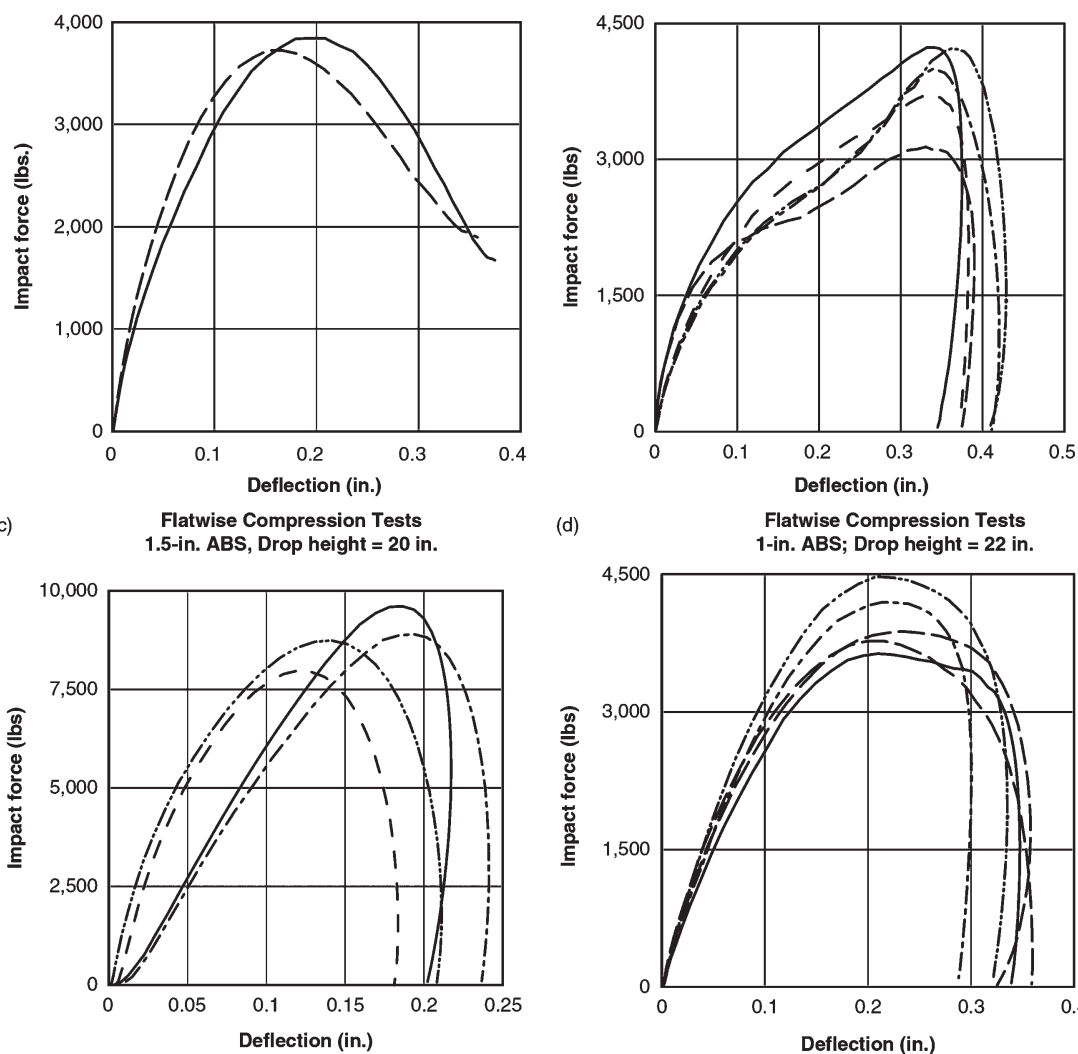

(d)
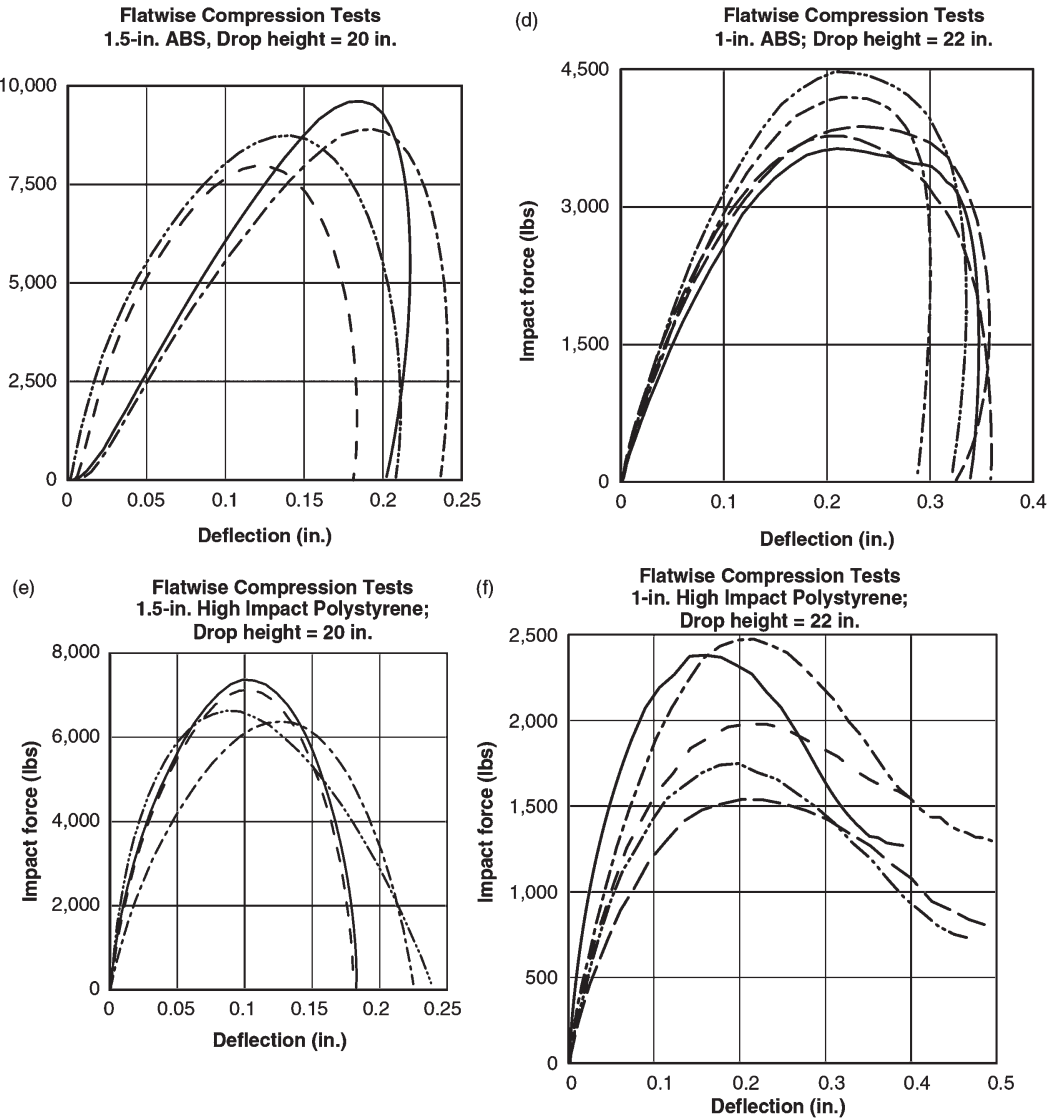

Figure 5. (a) I.5-in. thick polycarbonate (PC); (b) I-in. thick PC-regrind (PCR); (c) I.5-in. thick acrylonitrile butadiene styrene (ABS); (d) I-in. thick ABS; (e) I.5-in. thick high-impact polystyrene (HIPS); and (f) I-in. thick HIPS. 
Table 2. Flatwise compression drop weight test results

\begin{tabular}{|c|c|c|c|c|c|c|}
\hline Core material & $\begin{array}{l}\text { Core } \\
\text { height } \\
\text { (in.) }\end{array}$ & $\begin{array}{l}\text { Drop } \\
\text { height } \\
\text { (in.) }\end{array}$ & $\begin{array}{l}\text { Peak } \\
\text { stress } \\
\text { (psi) }\end{array}$ & $\begin{array}{l}\text { Impact } \\
\text { energy } \\
\text { (in.-lbs) }\end{array}$ & $\begin{array}{l}\text { Energy } \\
\text { absorption } \\
\text { (in.-lbs) }\end{array}$ & $\begin{array}{l}\text { Energy } \\
\text { absorption } \\
(\%)\end{array}$ \\
\hline Polycarbonate (PC) & 1.5 & 24 & 240 & 1735 & 1045 & 60 \\
\hline Polycarbonate (PC) & 1.5 & 24 & 233 & 1735 & 994 & 57 \\
\hline Polystyrene (HIPS) & 1.5 & 20 & 461 & 1446 & 980 & 68 \\
\hline Polystyrene (HIPS) & 1.5 & 20 & 446 & 1446 & 934 & 65 \\
\hline Polystyrene (HIPS) & 1.5 & 20 & 398 & 1446 & 1002 & 69 \\
\hline Polystyrene (HIPS) & 1.5 & 20 & 415 & 1446 & 1090 & 75 \\
\hline Polystyrene (HIPS) & 1.5 & 20 & 487 & 1446 & 1091 & 75 \\
\hline ABS & 1.5 & 20 & 601 & 1446 & 1260 & 87 \\
\hline$A B S$ & 1.5 & 20 & 498 & 1446 & 1040 & 72 \\
\hline ABS & 1.5 & 20 & 556 & 1446 & 1330 & 92 \\
\hline$A B S$ & 1.5 & 20 & 546 & 1446 & 1358 & 94 \\
\hline ABS & 1.5 & 20 & 549 & 1446 & 751 & 52 \\
\hline PC-regrind & 1.5 & 20 & 233 & 1446 & 1370 & 95 \\
\hline PC-regrind & I & 22 & 265 & $|59|$ & 1143 & 72 \\
\hline PC-regrind & I & 22 & 232 & $|59|$ & 1012 & 64 \\
\hline PC-regrind & I & 22 & 250 & $|59|$ & 1091 & 69 \\
\hline PC-regrind & I & 22 & 264 & $|59|$ & 1169 & 73 \\
\hline PC-regrind & 1 & 22 & 196 & $159 \mid$ & 924 & 58 \\
\hline Polystyrene (HIPS) & 1 & 22 & 149 & $|59|$ & 702 & 44 \\
\hline Polystyrene (HIPS) & I & 22 & 124 & $159 \mid$ & 636 & 40 \\
\hline Polystyrene (HIPS) & I & 22 & 155 & |59| & 887 & 56 \\
\hline Polystyrene (HIPS) & I & 22 & 109 & $|59|$ & 588 & 37 \\
\hline Polystyrene (HIPS) & I & 22 & 96 & $|59|$ & 572 & 36 \\
\hline $\mathrm{ABS}$ & I & 22 & 227 & |59| & 968 & 61 \\
\hline$A B S$ & 1 & 22 & 242 & $|59|$ & 1065 & 67 \\
\hline$A B S$ & I & 22 & 262 & $|59|$ & 929 & 58 \\
\hline$A B S$ & I & 22 & 280 & $|59|$ & 1125 & 7I \\
\hline$A B S$ & 1 & 22 & 236 & |59| & 1016 & 64 \\
\hline
\end{tabular}

ABS: acrylonitrile butadiene styrene; HIPS: high-impact polystyrene; I in.= $25.4 \mathrm{~mm}$; I psi $=6.9 \mathrm{kPa}$; and I in- $\mathrm{lb}=0.1 \mathrm{I} 3 \mathrm{~J}$.

\section{Flatwise compression tests}

A compression test specimen placed between two rigid steel plates is shown in Figure 4.

The total downward force during a drop weight test was monitored by a 200kip $(890 \mathrm{kN})$ load cell. Two linear variable differential transformers (LVDTs) were 


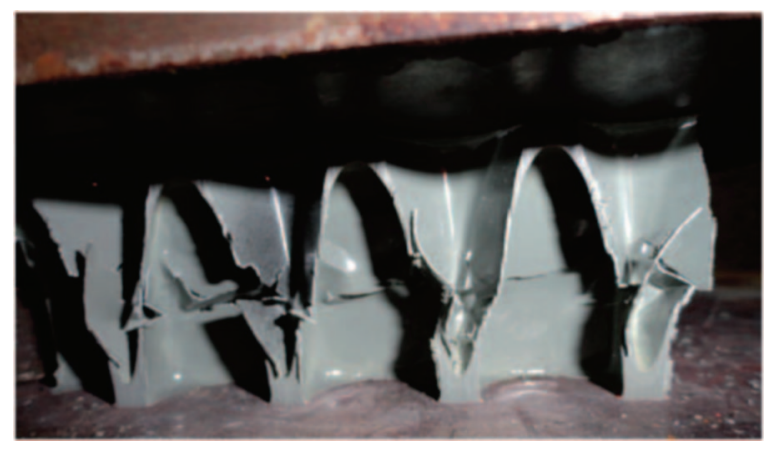

Figure 6. Failed high-impact polystyrene (HIPS) core under flatwise compression.

used to measure the relative displacement between the two steel plates. The average displacement is taken as the contraction in the core material. Strain gages were also mounted on the webs of some specimens to estimate the strain rate of the drop weight impact loading. C-clamps were used to snugly hold the top steel plate to prevent it from rebounding after impact. The strain, displacement, and force data traces were recorded by a data acquisition system at a sampling frequency of $4000 \mathrm{~Hz}$.

Figure 5(a) through (f) shows the load-deflection curves of different Norcore materials from the flatwise compression drop weight tests. The area under a load-deflection curve represents the capacity of impact energy absorption of the core material. The initial energy of the drop weight before impact, calculated as the drop weight times drop height, and the energy absorption capacities are presented in Table 2.

A failed 1.5-in. (38 mm) thick, high-impact polystyrene (HIPS) core is shown in Figure 6. One 1.5-in. HIPS and one 1.5-in. acrylonitrile butadiene styrene (ABS) specimens had a strain gage mounted vertically on the web to measure the strain rate. The strain rate appeared to be dependent upon the stiffness of the core materials. As shown in Figure 7, the peak strain rate in the ABS was about 11/sec at $0.002 \mathrm{sec}$ and that in HIPS was about $3 / \mathrm{sec}$ at $0.003 \mathrm{sec}$ after impact.

\section{Three-point bending tests}

All the sandwich panel specimens under bending drop weight tests were 12 in. $(305 \mathrm{~mm})$ long and 4 in. (102mm) wide core with 0.032-in. (0.81 mm) aluminum facings. The clear span between the simple supports was 9 in. (229 mm). The 1.5in. $(38 \mathrm{~mm})$ overhang at each end of the specimen was free to rotate. The test specimens were impacted at the mid-span by the drop weight. Two strain gages were mounted on the top facing at 2-in. $(51 \mathrm{~mm})$ distance on either side of the mid-span, and two strain gages were mounted on the bottom facing at the midspan. The displacement at the mid-span is monitored by a string potentiometer. Some specimens had additional strain gages mounted on the web at the mid- 


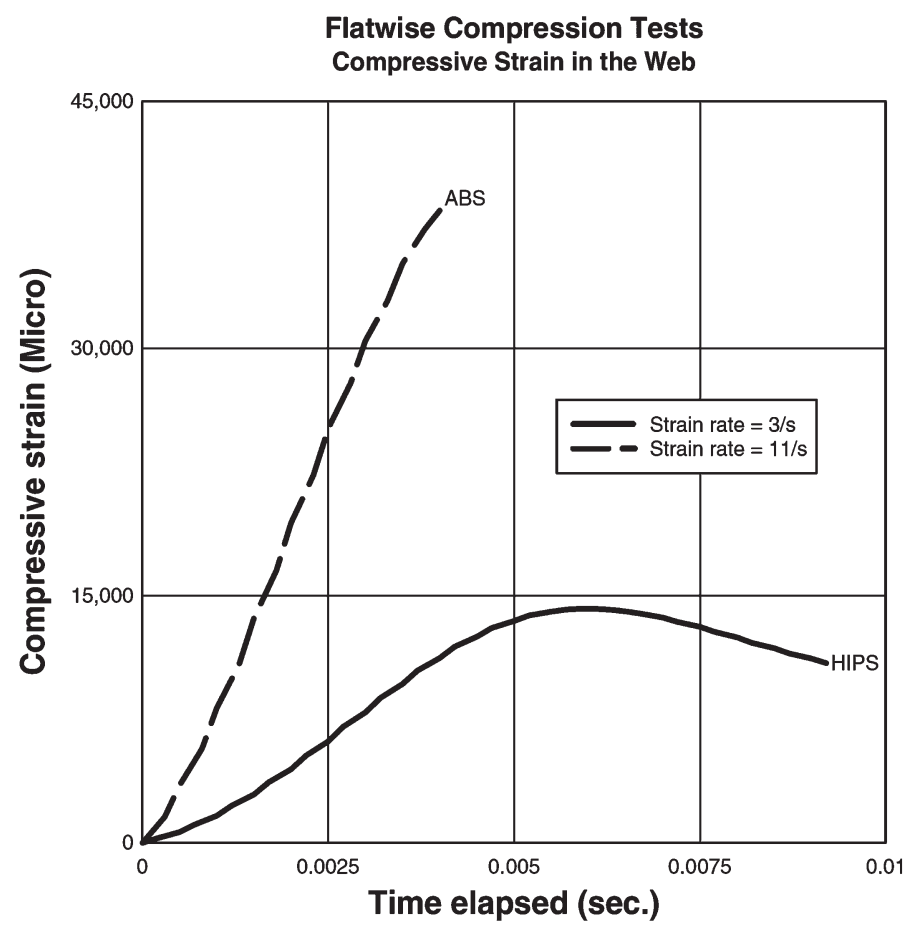

Figure 7. Strain rate of the flatwise compression drop weight tests.
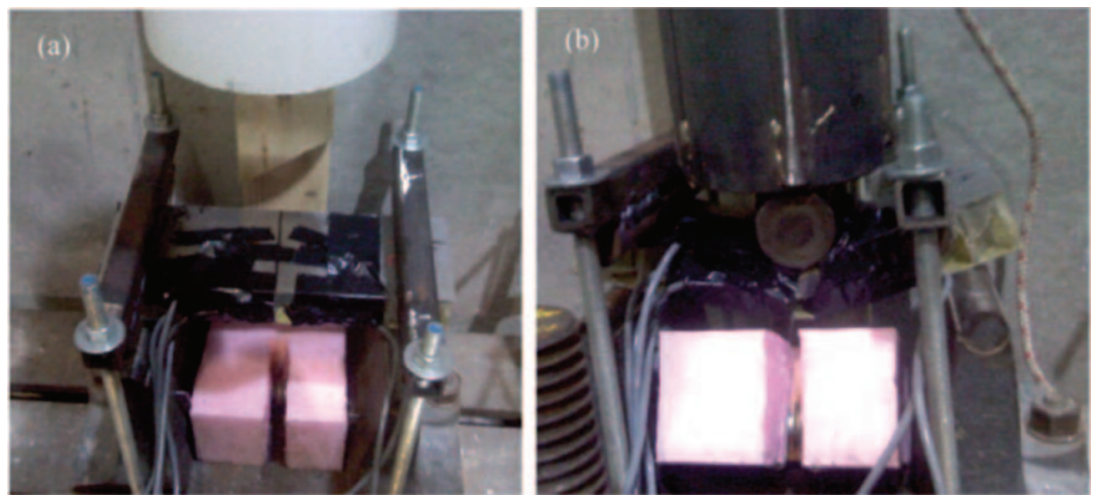

Figure 8. Drop weight bending test setup.

span to monitor the strain rate. Figure 8(a) shows a specimen before impact of the drop weight and Figure 8(b) shows the specimen after the impact.

Most common failure modes under a three-point bending test are local buckling or wrinkling in the top face, local yielding in the bottom face, crushing of 


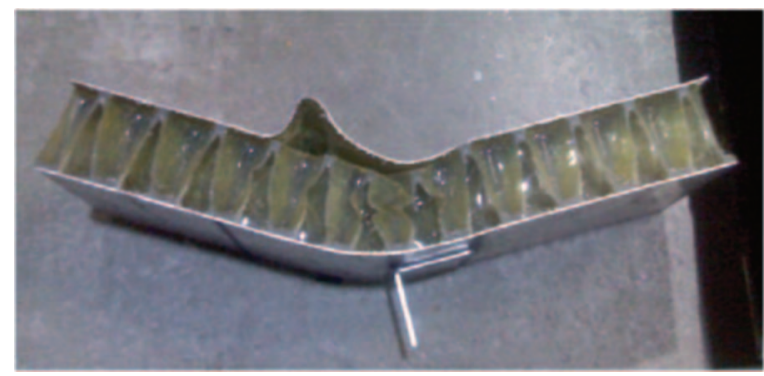

Figure 9. Failure modes observed in the flexural test.

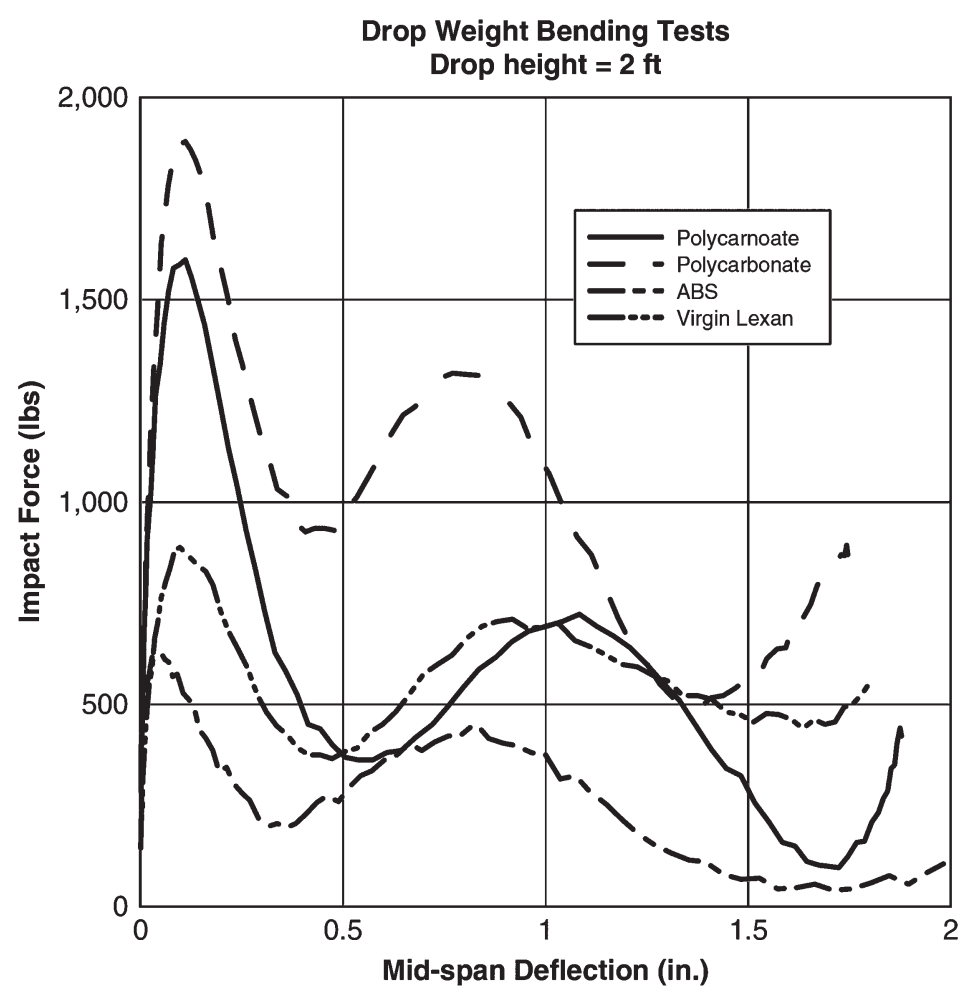

Figure 10. Load-deflection curves.

the core material, and bond failure between facing and the core, as shown in Figure 9.

The sandwich panels had 1.5-in. thick core made of polycarbonate, HIPS, ABS, and virgin Lexan. The load-deflection curves obtained from the drop weight 


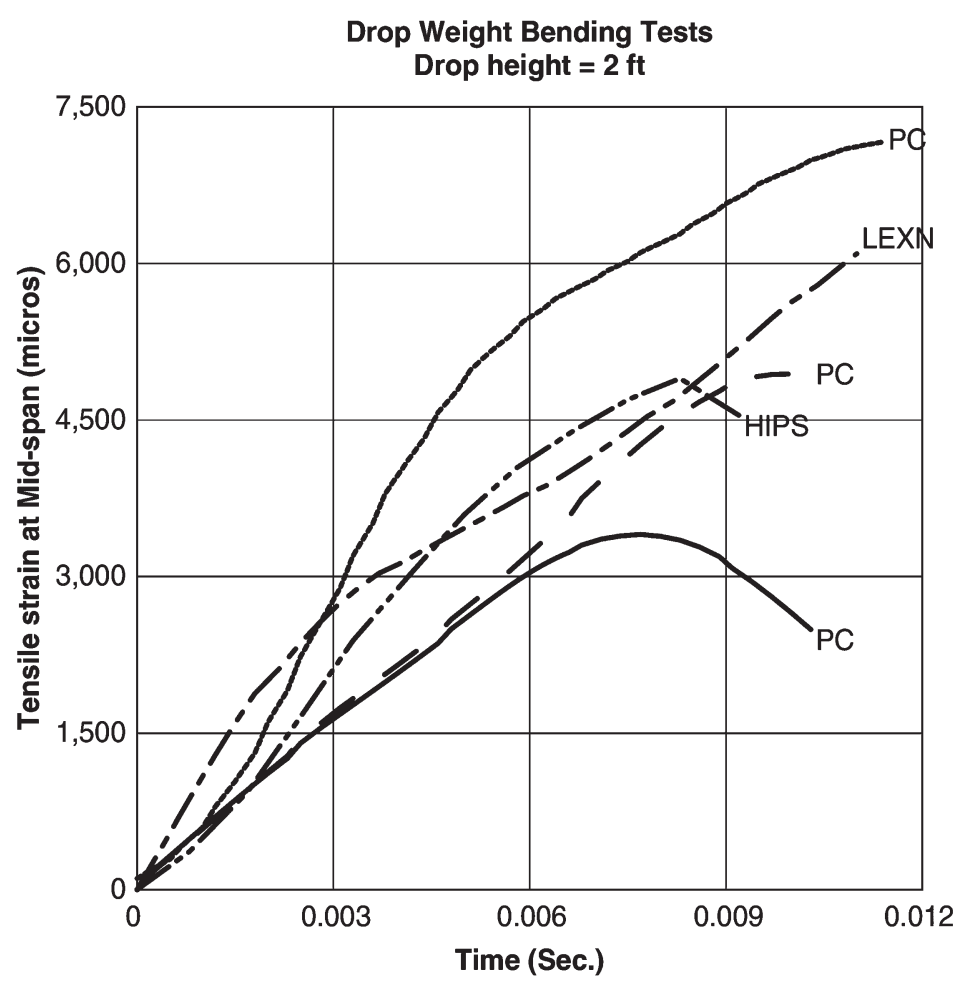

Figure II. Tensile strains in the bottom face at mid-span.

bending tests are compiled in Figure 10. The string potentiometer malfunctioned during the test of HIPS panel. It is evident that all the sandwich panels had fairly good strength and ductility for impact loading. The maximum mid-span deflection sustained was generally about 2 in., taking place within $0.02-0.03 \mathrm{sec}$ after impact. The undulations in the impact force (or support reactions) were probably due to oscillations of the beam after making contact with the drop weight.

Aluminum has an elastic modulus of 10_106 psi (69 GPa) and a yield point of 30-35 ksi (207-241 MPa). The tensile strains in the bottom face obtained are presented in Figure 11, where the bottom face yielded when the tensile strains reached about 3500 micro strains.

The compressive strains in the top face obtained are presented in Figure 12, where local wrinkling occurred in the face when the compressive stresses reached about $4 \mathrm{ksi}(28 \mathrm{MPa})$.

The strain rate of the drop weight bending tests can be estimated from the strain gages mounted vertically on the web of the sandwich core at the mid-span. The compressive strains thus obtained are presented in Figure 13. The strain rates obtained from the bending tests are remarkably close to those obtained in the flat- 


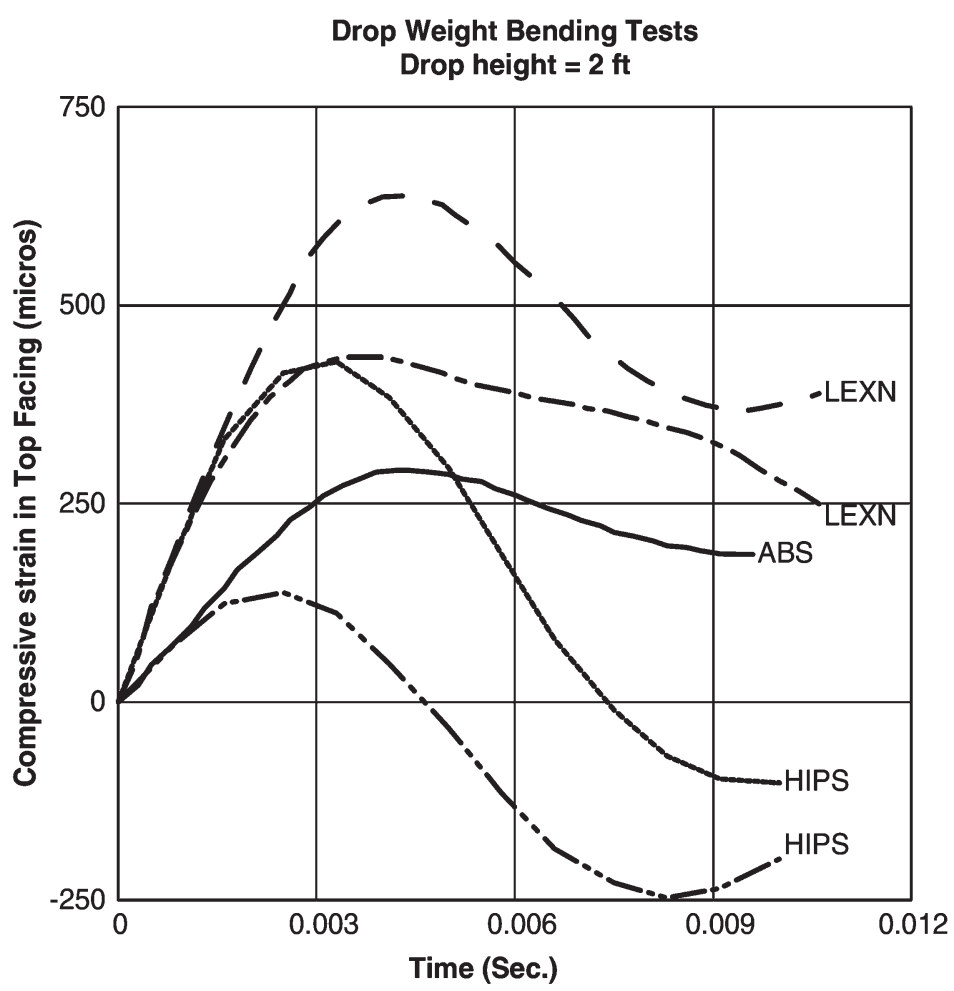

Figure 12. Compressive strains in the top face.

wise compression tests. The peak strain rate in the HIPS and Lexan was about 11 / sec at $0.002 \mathrm{sec}$ and that in PC was about 8 / sec at $0.001 \mathrm{sec}$ after impact.

\section{Discussions}

Sierakowski and Hughes [4] conducted a series of static flatwise compression and beam-bending tests on the sandwich panels with the Norcore materials. They also reported the results from dynamic compressive tests by using a Split Hopkinson Pressure Bar (SHPB). The average values from the drop weight tests are compared with their test results in Table 3. The flatwise compression drop weight test results compare fairly well with the SHPB test data, while the static test results are much higher in many cases. This could be due to early buckling of the web upon initial high-impact stress (see Figure 6), while the instability is delayed under static loading. On the contrary, the static bending test results [4] are lower than the drop weight test results and the published data by the manufacturer [2]. 


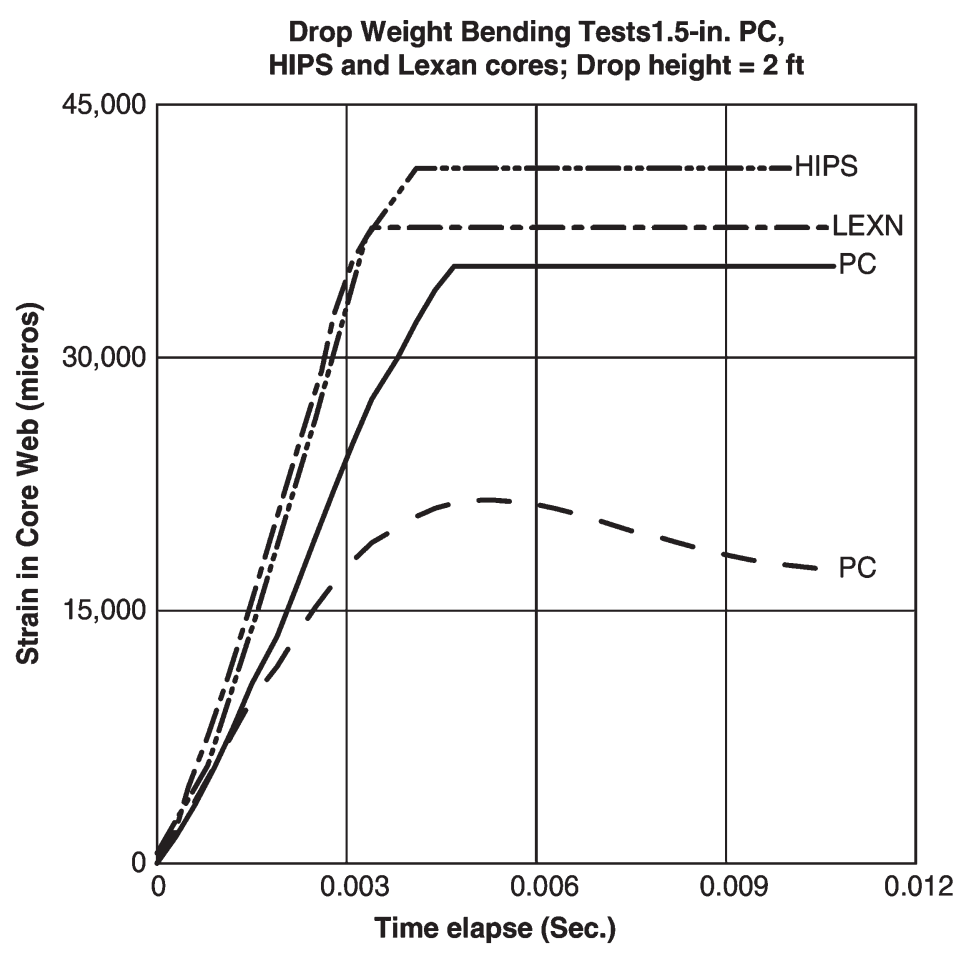

Figure 13. Compressive strains in the core web.

Table 3. Comparisons of drop weight test results vs. static test results [4].

\begin{tabular}{|c|c|c|c|c|c|c|c|}
\hline \multirow[b]{2}{*}{ Core material } & \multicolumn{4}{|c|}{ Flatwise compression tests (psi) } & \multicolumn{3}{|c|}{ Beam Bending Tests (lbs) } \\
\hline & $\begin{array}{l}\text { Core } \\
\text { height (in.) }\end{array}$ & $\begin{array}{l}\text { Drop } \\
\text { weight }\end{array}$ & Static [4] & SHPB & $\begin{array}{l}\text { Drop } \\
\text { weight }\end{array}$ & Static [4] & Static [2] \\
\hline Polycarbonate (PC) & 1.5 & 235 & 143 & 348 & 1745 & 448 & 1538 \\
\hline PC-regrind & 1 & 241 & 418 & 235 & - & 501 & - \\
\hline PC-regrind & 1.5 & 233 & 439 & 235 & - & 1103 & - \\
\hline Polystyrene (HIPS) & 1 & 127 & 658 & - & 690 & 655 & 1146 \\
\hline Polystyrene (HIPS) & 1.5 & 441 & 473 & 493 & - & 462 & - \\
\hline $\mathrm{ABS}$ & 1 & 249 & 605 & 410 & - & 726 & 1897 \\
\hline ABS & 1.5 & 550 & 815 & 484 & - & 1653 & - \\
\hline
\end{tabular}

ABS: acrylonitrile butadiene styrene; HIPS: high-impact polystyrene; SHPB: Split Hopkinson Pressure Bar; I in. $=25.4 \mathrm{~mm}$; I psi $=6.9 \mathrm{kPa}$; and I lb $=4.45 \mathrm{~N}$. 


\section{Conclusion}

The dynamic strength of a novel sandwich panel structure due to the impact of a drop weight was studied in detail. The results are compared to the static test results published in the literature. The drop weight tests were conducted in accordance with the ASTM C365 - flatwise compressive strength and the ASTM D790 - three-point loading flexural strength tests. The initial impact energy of the drop weight and the impact energy absorption capacities of several thermoplastic core materials are presented. The percentage energy absorption shows that, for the same core material, the $1.5 \mathrm{in}$. $(38 \mathrm{~mm})$ core absorbed more impact energy than the 1 -in. $(25 \mathrm{~mm})$ core did.

The test results have shown that these sandwich panels have good strength as well as good energy absorption capacities. The drop weight tests are easy to conduct and the tests are repeatable and reliable. Further drop weight testing should be conducted on sandwich panels with conventional core construction to compare impact energy absorption and weight savings characteristics against those of the Norcore panels.

Acknowledgment - The author wishes to thank Jeffrey Svatora and Kelvin Lein for their timely assistance in setting up the drop weight tests and the effort in acquiring data.

\section{References}

1. Gibson LJ and Ashby MF. Cellular solids. Oxford, UK: Pergamon Press, 1988.

2. Norfield Corporation. Technical data package. Danbury, CT: Norfield Corporation, 1995.

3. Tuan CY and Sierakowski RL. Numerical analysis of a novel thermoplastic sandwich core material. J Sandwich Struct Mater 2000; 2(3): 215-224.

4. Sierakowski RL and Hughes ML. Force protection using composite sandwich structures. Compos Sci Technol 2006; 66: 2500-2505. 